\title{
KONTRIBUSI KIAI SHALEH DARAT DALAM PENULISAN TAFSIR DI INDONESIA
}

\author{
Istianah \\ Institut Agama Islam Negeri Kudus \\ istianah@stainkudus.ac.id
}

\begin{abstract}
This article discusses the contribution of Kiai Shaleh Darat, a prominent Muslim scholar as well as a noticeable warrior against Western invaders, in writing Qur'anic commentaries in Indonesia. His Qur'anic commentary entitled Fayd al-Rabmān fì Tarjamat Tafsìr Kaläm Mālik al-Dayyān, written in Javanese-Arabic (pegon), is not only considered as a representation of Javanese identity, but also as a means of resistance against Dutch colonialism. Through interpretation, he is not only giving an understanding of the Qur'an, but also managing a resistance through the Qur'anic exegesis. That is because at that time the Dutch government forbade the translation of the Qur'an. This interpretation is written using the method of tablili (explanation) with Sufis nuance which becomes the spirit in each word of his interpretation. Shaleh Darat was greatly influenced by Sufism figures such as Imām al-Ghazāili through his Ihyà' 'Ulum al-Dīn and Ibn 'Atàillāh through his Hikam. Thi article eventually argues that Fayd al-Rabman has, at least, three contributive manifestations in the discourse of Indonesia Qur'anic interpretation: the Qur'anic sufism, cultural resistance, and community development in instilling the values of goodness.
\end{abstract}

Keywords: Shaleh Darat, Qur'anic Interpretation, Java, Sufism.

\begin{abstract}
Abstrak: Artikel ini membahas tentang kontribusi Kiai Shaleh Darat, seorang ulama sekaligus pejuang, dalam penulisan tafsir di Indonesia. Magnum opusnya, Fayd al-Rahmān fì Tarjamat Tafsir Kalam Mälik al-Dayyān, yang ditulis dengan Bahasa Arab Pegon, bukan hanya sebagai representasi identitas kejawaan, tetapi juga sebagai sarana perlawanan terhadap kolonial Belanda. Melalui tafsir yang ditulisnya, dia tidak hanya memberikan pemahaman tentang isi kandungan Alquran kepada masyarakat, tetapi sekaligus sebagai bentuk perlawanan, karena pada masa itu pemerintah Belanda melarang adanya penerjemahan Alquran. Tafsir ini ditulis menggunakan metode tablïi dengan corak sufistik yang menjadi ruh di setiap lembar penafsirannya. Shaleh Darat sangat terpengaruh dengan tokoh-tokoh tasawuf seperti Imām al-Ghazāili melalui Ihya' 'Ulum al-Dìn dan Ibn 'Atại illāh melalui Sharah Hikam. Dengan demikian, tafsir Fayd al-Rahmān setidaknya memiliki tiga manifestasi kontributif dalam penulisan tafsir di Indonesia, yaitu corak sufistik, perlawanan kultural, dan pembinaan masyarakat dalam menanamkan nilai-nilai kebaikan.
\end{abstract}

Kata kunci: Shaleh Darat, Tafsir Alquran, Jawa, Sufistik. 


\section{Pendahuluan}

Di Indonesia kajian tentang penulisan tafsir sebenarnya telah bergerak cukup lama dan mengalami perkembangan yang dinamis seiring dengan perkembangan sosial-budaya dan peradaban umat manusia. ${ }^{1}$ Hal ini terbukti dengan munculnya karya-karya tafsir dari mulai era klasik hingga kontemporer, dengan berbagai corak, metode, dan pendekatan yang digunakan.

Penulisan tafsir Alquran di Nusantara sebetulnya sudah ada sejak abad ke-16. Setidaknya dapat dilihat dari naskah Tafsir Surah Al-Kabfi [18]: 9. Teknis penulisan tafsir ini berdasarkan surah tertentu, yakni Surah al-Kahf, namun tidak diketahui siapa penulisnya. Satu abad kemudian, muncul karya tafsir Tarjumān al-Mustafid yang ditulis oleh 'Abd al-Ra'ú al-Sinkili (1615-1693 M) lengkap 30 juz. Kemudian pada abad ke-19 M muncul sebuah karya tafsir yang menggunakan bahasa Melayu-Jawi, yaitu Kitab Farä'id al-Qur'an. Tafsir ini juga tidak diketahui siapa penulisnya. Ditulis dalam bentuk yang sangat sederhana, karena hanya terdiri dari dua halaman dengan huruf kecil dan spasi rangkap. Ayat yang ditafsirkan adalah surah al-Nisā': 11 dan 12, yang berbicara mengenai hukum waris.

Kemudian pada abad ke-19 juga terdapat literatur tafsir yang ditulis oleh Imāam al-Nawawi al-Bantāni (1813-1879 M), yaitu Al-Tafsìr al-Munir li Ma'alim al-Tañīl. Tafsir ini ditulis di Makkah dan menggunakan bahasa Arab sebagai bahasa pengantarnya. Atas kecemerlangannya dalam menulis tafsir, ulama Mesir menggelari Imam al-Nawawi dengan "Sayyid 'Ulamā" al-Hijäz". Pada awal abad ke-20 M tradisi penulisan tafsir semakin berkembang, di antaranya ditulis oleh Mahmud Yunus, A. Hassan, T.M. Hasbi Ash-Shiddieqy, dan Hamka yang masing-masing menulis tafsir genap 30 juz dengan model penyajian runtut sesuai dengan urutan surah dalam mushaf 'Uthmāni. ${ }^{2}$

Salah satu ulama yang menduduki posisi penting dalam dinamika penafsiran Alquran di nusantara adalah Kiai Shaleh Darat (1820 M 1903 M). Ia merupakan seorang ulama, pujangga dan pejuang yang hidup di akhir abad ke-19 dan awal abad ke-20. Sebagai seorang ulama yang merangkap sebagai pejuang, dia gigih dalam melawan penjajah

1 Taufikur Rohman, "Kajian Tafsir di Indonesia," dalam Mutawatir Jurnal Keilmuan Tafsir Hadith, Vol. 2, No. 1 (2012), 1-26.

2 Islah Gusmian, Khazanah Tafsir Indonesia dari Hermeneutika hingga Ideologi Jakarta: Teraju, 2003), 54-56. 
dan menyebarkan agama Islam. Kehadirannya ibarat "cahaya" yang mampu memberikan penerangan dan pencerahan kepada masyarakat.

Shaleh Darat juga produktif, terbukti dengan banyaknya karyakarya yang dia tuliskan, kurang lebih 40 , meski yang bisa diselamatkan hanya sekitar 14 kitab. Hingga saat ini, kitab-kitab Shaleh Darat mulai banyak dikaji dan diterjemahkan ke dalam bahasa Indonesia. ${ }^{3} \mathrm{Di}$ antara karyanya yang paling monumental adalah tafsir Fayd al-Rahmān $\overline{f i}$ Tarjamat Tafsìr Kaläm Mälike al-Dayyān (Limpahan Rahmat Allah dalam Menerjemahkan Tafsir Firman-firman Allah Penguasa Hari Pembalasan). Dengan latar belakang perjuangan, dia berhasil mengawinkan sikap patriotik dengan framework sufistik. Dalam konteks inilah tulisan akan diarahkan untuk menelusuri latar mengapa dia memilih bentuk tersebut, dan apa kontribusi pemikirannya dalam bingkai penafsiran di Indonesia.

\section{Sketsa Biografi Kiai Shaleh Darat}

Muhammad Shaleh b. 'Umar al-Samarani, yang dikenal dengan sebutan Mbah Kiai Haji Shaleh Darat, dilahirkan di Kedung Jemplung Kecamatan Mayong Kabupaten Jepara pada tahun 1235/1820. Ayahnya bernama Kiai Umar b. Tasmin yang berasal dari Mayong Jepara. Kiai Umar dikenal sebagai ulama dan mitra perjuangan Panggeran Diponegoro. ${ }^{4}$

Kiai Shaleh lebih populer dengan sebutan Kiai Shaleh Darat. Ada dua alasan kenapa dipanggil "Kiai Shaleh Darat". Pertama, sesuai dengan akhir surah yang ia tujukan kepada Penghulu Tafsir Anom, penghulu Keraton Surakarta, yaitu: "Al-Haqir Muhammad Shaleh Darat" dan juga menulis nama "Muhammad Shaleh ibn 'Umar Darat Semarang" ketika menyebut nama-nama gurunya dalam kitab alMurshid al-Waji: Kedua, sebutan "Darat" diakui sendiri dalam sampul salah satu karyanya yang berjudul: Sharh Barzanjī. Nama "Darat" yang melekat di akhir namanya merupakan nama salah satu daerah di Semarang, yakni Kampung Melayu Darat. Dinamai "Darat", konon kampung ini merupakan tempat mendarat orang-orang dari luar Jawa. $^{5}$

${ }^{3}$ Imam Musbikin, Mutiara al-Qur'an (Yogyakarta: Jaya Star Nine, 2014), 200.

${ }^{4}$ Kiai Shaleh Darat, Syarah al-Hikam: Kyai Shaleh Darat, Maha Guru Ulama Besar Nusatara 1820-1903, terj. Miftahul Ulum dan Agustin Mufarohah (Depok: Penerbit Sahifa, 2016), xxv.

${ }^{5}$ Musbikin, Mutiara al-Qur'an, 198. 
Aktivitas keilmuan Shaleh Darat ditempuh dari pesantren ke pesantren dan pernah berguru pada sejumlah Kiai di kawasan Pantura, seperti Kiai Syahid, pengasuh pondok Pesantran di Waturoyo Margoyoso Kajen. Kiai Syahid adalah cucu Kiai Mutamakkin yang hidup semasa Paku Buwono II (1727-1749 M). Dari beliaulah Kiai Shaleh belajar kitab Fath al-Qarib, Fath al-Muīin, Minhäj al-Qawìm, Sharḅ al-Khațib, Fath al-Wabhäb, dan lain sebagainya.

Kiai Shaleh juga menimba ilmu (nyantri) pada Kiai Raden Haji Muhammad Shaleh b. Asmani Kudus dengan belajar Tafsir al-Jalälayn. Pada Kiai Ishaq Damaran dia belajar Nạ̣w dan Șaraf, belajar Ilmu Falak pada Kiai Abu Abdillah Muhammad b. Hadi Baiquni. Beliau seorang mufti di Semarang. Mengaji kitab Jawhar al-Tawhịd dan Minbäj al-'ÁAidin pada Kiai Ahmad Bafaqih Ba'ahvi dari Semarang, mengaji kitab al-Masäil al-Sittin pada Shaykh Abdul al-Ghani Bima dari Semarang. Dengan Kiai Ahmad Alimlah, Shaleh Darat mempelajari ilmu-ilmu yang berkaitan dengan tasawuf dan tafsir Alquran. Kemudian diperbantukan Kiai Zain al-Alim untuk mengasuh sebuah pesantran di dukuh Salatiang, Desa Maron Kecamatan Loana Purworejo. Melihat keragaman kitab-kitab yang dipelajari Kiai Shaleh Darat dari beberapa gurunya, ini menunjukkan konsistensi beliau dalam menekuni ilmu agama dan sekaligus menunjukkan kepakarannya dalam keilmuan. ${ }^{6}$

Pada abad ke-19, Shaleh Darat bersama dengan Sang ayah berangkat ke Makkah. Selama di Mekah Shaleh Darat berguru dengan beberapa ulama Haramain. ${ }^{7}$ Pada waktu itu, di Haramain telah ada komunitas ulama Jawi (Biläd al-Jâwah), yakni komunitas para ulama dan santri yang berasal dari kawasan Asia Tenggara yang bermukim di Makkah guna memperdalam ilmu agama. Nama-nama gurunya antara lain Shaykh Muḥammad al-Maqri al-Mașri al-Makki, darinya dia belajar ilmu akidah, khususnya kitab 'Umm al-Barahin (karya alSānūsi). Kemudian dengan Shaykh Muhammad b. Sulaymān Hasballāh belajar Fiqh kitab Fath al-Wahäb dan Sharb al-Khatīib. ${ }^{8}$

Kemudian juga berguru pada Sayyid Aḥmad b. Zayni Daḥlan (seorang mufti Mazhab Shāfīīyah di Mekkah) untuk belajar Kitab

\footnotetext{
${ }^{6}$ Ibid., xxviii.

7 Taufiq Hakim, Kyai Shaleh Darat dan Dinamika Politik di Nusantara Abad XIX-XX (Yogyakarta: INDeS, 2016), 57.

8 Ibid., 66.
} 
Ibyà' Ulum al-din. Dia juga belajar kitab al-Hikam karya Ibn 'Atạ'illāh dengan Sayyid Muhammad Șaleh al-Zawawi al-Makki (salah seorang guru di Masjid al-Nabawi), belajar kitab Fatḥ al-Wabhāb Shaykh Aḥmad al-Naḥrawi al-Mișri al-Makki; Kiai Zāhid dan Shaykh 'Umar al-Shāmi; belajar kitab Sharḅ al-Tahrir. Dengan Shaykh Yüsuf alSanbalāwi al-Mișri. Shaleh Darat juga belajar tafsir Alquran dengan Shaykh Jamāl seorang mufti mazhab Ḥanafiyah di Makkah.'

Sejumlah tokoh di Nusantara yang pernah berguru dengan Shaleh Darat adalah: Kiai Hasyim Asy'ari (pendiri Nahdatul Ulama), Kiai Ahmad dahlan (Pendiri Muhammadiah), Kiai R. Dahlan Termas seorang ahli Falak, Kiai Amir pekalongan (w.1939 M) yang juga menantu Kiai Shaleh Darat, Kiai Idris Solo (w.1927 M), Kiai Hasan b. Sya'ban Semarang (w.1946 M), Kiai Abdul Hamid Kendal (w. 1930 M), Kiai Taher penerus pondok pesantren Mangkang Wetan, Kiai Sahli salah seorang Kiai di Kauman Semarang, Kiai Dimyati Termas, Kiai Khalil Rembang (w. 1940 M), Kiai Munawir Krapayak Yogyakarta (w. 1940 M), Kiai Dahlan Watucongol Muntilan Magelang, Kiai Yasin Rembang, Kiai Ridwan ibn Mujahid Semarang (w. 1950 M), Kiai Abdul Shomad Surakarta, Kiai Tafsir Anom Penghulu Keraton Surakarta, Kiai Yasir Areng Rembang, R.A Kartini Jepara. ${ }^{10}$ Shaleh Darat wafat pada hari Jum'at, 28 Ramadhan $1321 \mathrm{H} /$ 18 Desember 1903 M, dalam usia 83 tahun. Jenazahnya dimakamkan di Pemakaman Umum Bergota Semarang. ${ }^{11}$

\section{Latar Belakang Penulisan Tafsir Fayḍ al-Raḥmān}

Kitab tafsir Fayd al-Rahmān ditulis dalam kondisi dan situasi menguatnya cengkraman kolonial Belanda dan mengakarnya tradisi Islam Jawa. Pada masa itu, menerjemahkan Alquran dianggap sebagai hal yang "tabu", ditambah lagi adanya peraturan Belanda yang melarang keras penerjemahan Alquran. Sehingga para kiai tidak berani untuk menerjemahkan Alquran. Shaleh Darat sebagai salah satu ulama yang berani melawan arus dengan melakukan perlawanan terhadap Belanda. Atas keberaniannya, Shaleh Darat tidak hanya berhadapan

\footnotetext{
${ }^{9}$ Darat, Syarah al-Hikam, xvi.

${ }^{10}$ Ibid., xxxvi.

11 Ibid., xxv.
} 
dengan Pemerintah Belanda, tetapi juga ditentang bahkan dimusuhi dan difitnah oleh para kiai yang tidak sepaham dengan pemikirannya. ${ }^{12}$

Adapun penulisan tafsir Fayd al-Rahmān dilatar belakangi adanya kondisi masyarakat pribumi yang masih awam dalam bidang keagamaan. Pada era Belanda, masyarakat pribumi hanya diperbolehkan belajar membaca Alquran sehingga masyarakat tidak tahu arti dari ayat yang dibaca. Melihat kondisi yang demikian, Shaleh Darat memberanikan diri menulis sebuah karya tafsir. Tafsir ini ditulis agar masyarakat yang masih awam dalam bidang agama bisa belajar dan memahami isi kandungan Alquran. Sebagaimana yang dijelaskan dalam mukaddimah tafsirnya:

“...Ana toh ora pada angen-angen para manungsa kabeh ing maknane Alquran, kang wus nurunake ingsun ing Qur'an. Supaya podo angen-angenna para manungsa ing ayate Qur'an mangka arah mengkana mangka dadi neja ingsun gawe terjemahe maknane Qur'an. ${ }^{13}$

Tafsir Fayd al-Raḥmān ditulis dengan menggunakan Bahasa Arab pegon. Dengan mengusung Bahasa Arab Pegon, pada hakikatnya Shaleh Darat telah meletakkan prinsip-prinsip yang kuat bagi pembentukan tradisi pesantren. Hal ini ditempuhnya dalam rangka untuk meneguhkan identitas kultural sebagai bentuk perlawanan terhadap arogansi kolonialisme yang sewenang-wenang dan berusaha menggusur budaya pribumi kemudian digantikan dengan budaya kolonial. $^{14}$

Dalam mukadimahnya, Shaleh Darat menjelaskan penulisan pegon sebagai siasat mengelabuhi Belanda, karena pada waktu itu Belanda melarang menerjemahkan Alquran ke dalam bahasa Melayu atau Jawa. ${ }^{15}$ Mayoritas karya beliau menggunakan aksara pegon. Di tengah kekuasaan rezim kolonial Belanda, salah satu yang diawasi adalah pemikiran pribumi termasuk tingkat pemahaman orang-orang pribumi terhadap agamanya (Islam). Atas jasa beliau, masyarakat Jawa

\footnotetext{
12 Wawancara dengan Lukman Hakim Sektiawan, salah satu cicit Kiai Shaleh Darat, pada tanggal 15 Mei 2018.

13 Muhammad Șälih b. 'Umar al-Samarāni, Tafsir Fayd al-Rahmān $\bar{f}$ Tarjamat Tafsìr Kaläm al-Malike al-Dayyān (Mesir: t.t., 1935), 2.

14 Islah Gusmian, "Bahasa dan Aksara dalam Penulisan Tafsir Al-Qur'an di Indonesia Era Awal Abad 20 M," dalam Mutawatir Jurnal Keilmuan Tafsir Hadith, Vol. 5, No. 2 (2015), 223-247.

15 Al-Samarāni, Fayd al-Raḅmān, vol. 1, 1.
} 
semakin banyak mengetahui tentang ajaran Islam. Disamping itu, tidak hanya mempertimbangkan masyarakat Jawa sebagai basis pembaca karya tafsirnya, tetapi secara politik juga sebagai salah satu bentuk perlawanan terhadap pemerintah Belanda.

Larangan menerjemahkan Alquran juga didukung oleh satu keyakinan di kalangan sebagian pemeluk agama Islam bahwa menerjemahkan dan menafsirkan Alquran ke dalam selain bahasa Arab hukumnya haram. Ditambah lagi pada awal tahun 1900-an Sayyid 'Uthmān (1822-1913), ulama Batawi asal Hadramaut pernah menulis buku yang berjudul "Al-Rahmān bi al-Naby Tarjamat al-Qur'an" (Hukum Tuhan berkaitan dengan larangan Menerjemahkan Alquran 1327/1909). Dalam buku tersebut, ia menegaskan bahwa haram hukumnya menerjemahkan Alquran, baik dalam bentuk tulisan maupun lisan. Fatwa ini secara politik menguntungkan pemerintah Belanda, dan pada sisi yang lain umat Islam di kalangan orang awam akan kesulitan memahami isi kandungan Alquran karena hambatan bahasa. R.A. Kartini termasuk salah satu yang menentang paham tersebut. ${ }^{16}$

Tafsir Fayd al-Rahmān terdiri dari dua jilid dan baru sampai Surah al-Nisā'. Jilid pertama terdiri dari dua naskah: naskah pertama tebalnya 270 halaman dan naskah kedua 577 halaman. Jilid pertama berisi surah al-Fätihah dan al-Baqarah, tebalnya keseluruhan 1282 halaman. Untuk jilid pertama ditulis pada hari Jum'at malam Kamis 20 Rajab 1309 H/19 Februari 1892 M dan selesai pada hari Jum'at 7 Muharram $1311 \mathrm{H} / 21$ Juli 1893. Jilid yang kedua berisi surah Āli-'Imrān dan alNisā' yang terdiri dari 705 halaman. Jilid kedua ini mulai ditulis pada hari Jum'at 20 Jumadil Akhir 1310 H/9 Januari 1893 dan selesai pada Hari Selasa 19 safar 1312 H/ 22 Agustus 1894. Jilid kedua ini dicetak oleh percetakan yang sama untuk jilid pertama pada tahun 1312/1894, yaitu dicetak di Singapura oleh Percetakan Haji Muhammad Amin pada tanggal 27 Rabi'ul Akhir $1311 \mathrm{H} / 7$ Nopember 1893 M. $^{17}$

Pada awalnya Shaleh Darat belum bersedia mempublikasikan karya tafsirnya yang belum selesai. Namun atas dorongan dan permintaan santri-santri yang ingin membaca, dia kemudian membertimbangkannya. Sebelum dipublikasikan, Shaleh Darat melakukan salat istikharah, dalam istikharahnya dia mendapat isyarat

\footnotetext{
${ }^{16}$ Islah Gusmian, Dinamika Tafsir al-Qur'an Bahasa Jawa (Surakarta: EFUDE PRESS, 2015), 135-137.

${ }^{17}$ Amirul Ulum, Kartini Nyantri (Yogyakarta: Pustaka Ulama, 2016), 177.
} 
bahwa Allah telah memberi izin untuk mempublikasikan karya tafsirnya yang belum selesai itu. Akhirnya tafsir Fayd al-Rahmān dipublikasikan demi untuk memenuhi permintaan para santrinya meskipun belum selesai 30 juz. Kemudian Shaleh Darat menegaskan: “...Nuli pada nyuwun setengahe murid lan uga banget hajate mahu murid marang iki tarjamah tafsir, lan iya hajat liyane para murid. Hajat angaweruhi iki tafsir maka isih durung kersa, amarga durung kasih rampung kabeh. Kerana adate ulama mutaqaddimin rahimahumullah wanafa'anan bi'ulumihim amin iku ora kersa nyebarake karangane yen durung babar pisan, sakwuse mengkoko saking bangete kencenge karepe kang pada nyuwun mahu, nuli istikharah, nyuwun izin apatoh kelilan disebarake disik apa to hora. Maka den paring isaroh kon nyebarake."18

Sebenarnya Shaleh Darat hendak menyelesaikan tafsirnya hingga 30 juz, namun baru sampai juz 6 beliau wafat. Setelah Shaleh Darat wafat, dari sekian santri-santrinya tidak ada yang berkenan melanjutkan. Ditambah lagi setelah kepergian Shaleh Darat, kondisi pesantren sangat memprihatinkan. Pesantren dipegang oleh cantriknya yang berambisi untuk menguasainya. Kondisi yang demikian, membuat Belanda dengan leluasa bisa keluar masuk ke dalam pesantren. Sehingga banyak santri yang tidak betah, akhirnya para santrinya satu persatu pergi meninggalkan pesantren. Setelah itu pesantren dikuasai oleh PKI dan dijadikan sebagai tempat pelacuran dan kegiatan negatif lain. ${ }^{19}$

Ada anggapan bahwa penulisan tafsir Fayd al-Rahmān atas permintaan Kartini. Namun bila dirunut dari tahun penulisan tafsir Fayd al-Rahmān, bahwa tafsir tersebut pertama kali ditulis pada malam Kamis 20 Rajab 1309 H/ 19 Pebruari 1892 M. ${ }^{20}$ Sementara Kartini dilahirkan pada tanggal 21 April 1879. Pada awal tahun 1892, Kartini baru saja lulus Europeesche Lagere School (sekolah dasar untuk orang Eropa). Di usianya yang belum genap 13 tahun, oleh ayahnya harus menjalani pingitan. Pada tanggal 6 November 1899 Kartini berkirim surah kepada Nona E.H. Zeehandelaar yang menceritakan kondisi yang dialaminya, yaitu masyarakat hanya diajarkan untuk membaca Alquran, tanpa diajarkan untuk mengetahui dan mempelajari isi

\footnotetext{
18 Al-Samarāni, Fayd al-Rahmān, vol. 1, 1.

19 Wawancara dengan Lukman Hakim Sektiawan salah satu cicit Kiai Shaleh Darat, pada tanggal 15 Juli 2018.

${ }^{20}$ Ulum, Kartini Nyantri, 178.
} 
kandungannya. ${ }^{21}$ Jauh sebelum Kartini menulis surahnya, Shaleh Darat sudah menulis tafsirnya. Dari pernyataan di atas, semakin menguatkan bahwa penulisan tafsir Fayd al-Rahmān bukan atas permintaan Kartini, namun atas dorongan dan keinginan Shaleh Darat agar masyarakat awam, khususnya di Jawa, bisa memahami ajaran Islam.

\section{Metode, Corak, dan Sistematika Penulisan Tafsir Fayḍ al- Rahmān}

Tafsir Fayd al-Rahman ditulis dengan menggunakan metode taḅliti, dengan langkah-langkah sebagai berikut: ${ }^{22}$

a. Menafsirkan ayat-ayat Alquran secara terperinci dari mulai surah al-Fätihah sampai surah al-Nisā' sesuai dengan urutan ayat berdasarkan mushaf Alquran.

b. Menjelaskan nama surah termasuk Makkiyah atau Madaniyyah dan memberikan keterangan, tujuan, serta isi kandungan ayat.

c. Menafsirkan ayat demi ayat namun tidak disertakan nomor ayat maupun nama surah.

d. Menjelaskan penafsiran dengan ungkapan-ungkapan istilah bahasa lokal (Jawa) dan kadang juga menjelaskan ungkapanungkapan bahasa Arab, beserta ilmu nahw dan saraf-nya.

e. Menjelaskan ayat yang ada asbāb al-nuгū serta menukil pendapat para mufassir klasik, dan tokoh-tokoh tasawuf. ${ }^{23}$

${ }^{21}$ Tim Buku Tempo, Gelap-Terang Hidup Kartini, Perempuan-perempuan Perkasa (Bogor: PT GrafikaMardi Yuana, 2018), 33.

22 Metode Tabliti adalah salah satu metode tafsir dalam menafsirkan ayat-ayat alQur'an dengan memaparkan segala aspek yang terkandung di dalam ayat-ayat yang ditafsirkan serta menerangkan makna-makna yang tercakup di dalamnya sesuai dengan keahlian dan kecenderungan mufasir yang menafsirkan ayat-ayat tersebut. Mufasir dalam menafsirkan ayat-ayat Alquran secara runtut dari awal hingga akhirnya, dan surah demi surah sesuai dengan urutan maushaf (tartib mushafi). Menguraikan kosakata dan lafaz, menjelaskan arti yang dikehendaki, unsur-unsur i'jaz dan balaghah, kandungannya dalam berbagai aspek pengetahuan dan hukum. Juga aspek asbab al-nuzul suatu ayat, munasabah (hubungan) ayat-ayat Alquran antara satu sama yang lain. Lihat Nasruddin Baidan, Metodologi penafsiran al-Qur'an (Yogyakarta: Pustaka Pelajar, 2000), 31.

${ }^{23}$ Lilik Faiqoh, "Vernakularisasi dalam Tafsir Nusantara: Kajian atas Tafsir Faid alRahman Karya Kiai Shaleh Darat," dalam Jurnal Living Islam, vol. 01, no, 01 (2018), 99. 
Adapun sistematika penulisan tafsir Fayd al-Raḥmān termasuk dalam kategori tartib muşăa $\bar{i}$ (sesuai susunan/runtutan mushaf). Penyusunannya dimulai dari surah al-Fätihah sampai surah al-Nisā yang dimulai dengan memberi penjelasan nama surah dan turunnya surah, pendapat ulama tentang turunnya surah, jumlah ayat, kalimat dan huruf dalam surah, serta tujuan dan isi kandungan ayat.

Secara teknis, tafsir ini ditulis dengan mengikuti tartib surah sebagaimana yang ada dalam mushaf 'Uthmani. Ayat demi ayat disebutkan kemudian diberi penjelasan dan kadang ada dua ayat yang ditulis berurutan kemudian dijelaskan. Sebagaimana dalam surah alBaqarah [2]: 94-95 (Jilid I halaman 203). Ada juga satu ayat yang dipisah menjadi tiga bagian dengan penjelasan masing-masing, seperti dalam surah al-Baqarah [2]: 25 (jilid I halaman 87).

Shaleh Darat juga menggunakan tingkat bahasa yang beragam. Pada satu kesempatan memakai Bahasa Jawa Ngoko, misalnya pada bagian awal dari tafsirnya dia menulis: "ono to ora podho angen-angen manuso kabeh ing maknane Qur'an. Wus anurunaken ing Alquran supaya padha angen-angen manusa kabeh ing ayate Qur'an." 24 Pada kesempatan yang lain memakai Bahasa Jawa Krama, misalnya: "Nyembah kulo ing Tuban, keranten Tuban kan ndamel kula. Nunun tulung kula ing Tuban ing keranten Tuhan ingkang kula maksud." Beberapa kata Arab juga dipakai, misalnya, "I'lam, weruba sira mukallaf setubune kalimat albamdulillah iku kalimat kang mulya lan agung fadbilahe. Maka wajib arep ngreksa ing iki kalimah, aja kasib den muqabalahaken marang barang kang maksiat utawa barang kang ina mungguh syara'." ${ }^{25}$ Namun secara keseluruhan dalam karya tafsirnya, Shaleh Darat lebih banyak memakai Bahasa Jawa Ngoko dari pada memakai Bahasa Jawa Krama dan Bahasa Arab. Sejumlah kosa kata Arab yang dipakai, secara umum, diserap dari Bahasa yang populer di kalangan para santri di pesantren, seperti kata mukallaf, fadbilah, syara' dan ma'siyat. Salah satu contoh ketika menafsirkan (QS. al-Faatihah [1]: 1):

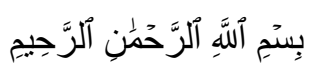

Sebelum menafsirkannya, dia terlebih dahulu menjelaskan secara singkat sebagai berikut:

"Surah al-Fātihah tergolong surah Makiyyah yang diturunkan sebelum hijrah, dengan merujuk pendapat Imam Baidhawi dan beberapa mayoritas ulama'. Surah al-Fatihah diturunkan setelah

24 Al-Samarāni, Fayd al-Raḅmān, vol. 1, 123.

${ }^{25}$ Ibid., 124. 
difardhukan shalat maktubah, dan setelah turunnya Surah al-Alaq dan Surah al-Muddastsir. Kemudian merujuk pendapat Imam Mujahid: "Sesungguhnya surah al-Fātiḥah itu turun setelah hijrah, yaitu pada saat shalat dipalingkan ke arah Ka'bah. Oleh sebab itu, surah ini tergolong Madaniyah." Sebagian ulama tafsir berpendapat bahwa surah al-Fätihah ini turun dua kali, sebagian diturunkan di Mekkah dan sebagian di Madinah. Menurut Imam Syafi'i surah al-Fätihah terdiri 7 ayat termasuk Basmalah, yang terdiri dari 27 kalimah dan 40 huruf, selain huruf yang bertasydid." 26

Kemudian dilanjutkan dengan menafsirkan "bismillah", Shaleh Darat menjelaskannya sebagai berikut: Saya salat dengan menyebut nama zat Allah yang bersifatan dengan sifat Jalal dan Qabhär, dan inilah apa yang ditunjukkan oleh lafal al-Rabman dan zat yang bersifatan dengan sifat Kamăl, dan inilah apa yang ditunjukkan oleh lafal al-rahim. Dalam kalimat "basmalah" terdapat empat martabat (kedudukan): pertama adalah martabatnya asmä' Allah. Kedua, adalah martabatnya Dzat dan lafal Allah. Ketiga adalah martabatnya sifat Jaläl. Keempat, adalah martabatnya sifat Jamāl yang sempurna. Oleh karena itu ayat tersebut mengisyaratkan adanya empat martabat, yaitu ulübiyah, rubübiyah, jismāniyah dan bayawāinyah.

Pada hakikatnya makna basmalah adalah wujud Allah dengan zatNya sendiri, dan semua sifat-sifat Allah ada yang dari sifat Jaläl (keMaha-Agung-an) dan sifat Jamāl (ke-Maha-Indah-an) Allah. Maka karena zat Allah semua yang ada, dan yang berdiri sendiri, atas izin Allah semua makhluk menjadi ada. Atas izin Allah semua mawjüd itu menjadi terlihat. Selain itu, Allah yang menyediakan sebab kebutuhan hidup semua makhluknya itu dengan sifat rabman-Nya serta mengangkat derajat orang yang ahli mendekatkan diri kepada Allah dan ahli karamah dengan sifat rabim-Nya. Semua itu merupakan isyarat dari manifestasi Jalăl dan Jamăl Allah. ${ }^{27}$

Setelah mengulas secara panjang lebar sifat rabmān dan rahim Allah, Shaleh Darat kemudian menekankan pentingnya sifat welas asih (kasih sayang) kepada sesama. Dari pernyataan tersebut dapat digarisbawahi bahwa dalam kehidupan harus ada keseimbangan, baik secara vertikal maupun secara horizontal.

${ }^{26}$ Ibid., 5 .

${ }^{27}$ Ibid., 4. 
Sedangkan jika dilihat dari coraknya, tafsir Fayd al-Rahmān lebih condong kepada corak sufistik dan corak ini telah menjadi ruh hampir di setiap lembarannya. Shaleh Darat sangat piawai dalam mengaitkan penjelasan keagamaan dengan fenomena riil yang dihadapi masyarakat. Dengan nuansa corak sufinya, Shaleh Darat terpengaruh dengan tokoh-tokoh tasawuf seperti Imām al-Ghazāil melalui Ibya a, 'Ulüm al-Dìn dan Ibn 'Atạ'illāh melalui Hikam. Keterpengaruhan tersebut dapat diketahui dari karya-karya Shaleh Darat yang merespons kitab-kitab al-Ghazāi dan Ibn 'Ațā'illāh.

Salah satu contoh penafsirannya dalam QS. al-Baqarah [2]: 173 adalah sebagai berikut:

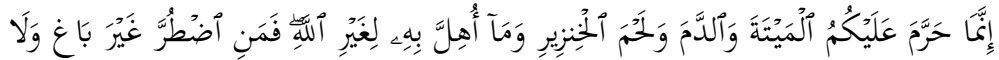

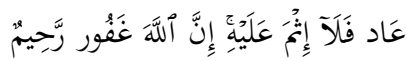

"Sesungguhnya Allah hanya mengharamkan bagimu bangkai, darah, daging babi, dan binatang yang (ketika disembelih) disebut (nama) selain Allah. Tetapi barang siapa dalam keadaan terpaksa (memakannya) sedang dia tidak menginginkannya dan tidak (pula) melampaui batas, maka tidak ada dosa baginya. Sesungguhnya Allah Maha Pengampun lagi Maha Penyayang."

Shaleh Darat menjelaskan makna ishäri dari kata khinzir yang arti leksikalnya adalah babi menjadi bermakna nafsu. Allah telah mengharamkan atas batin yang melihat selain Allah dari apa-apa yang ada. Maka ungkapan dan isyarat dari bangkai adalah harta benda. Haram untuk cinta terhadap dunia melebihi cintanya kepada Allah. Nafsu diumpamakan dengan babi karena sangat hina baik secara lahir dan batin. Sedangkan perumpamaan al-damm (darah) adalah al-shabwah al-nafsaniyah (hawa nafsu). ${ }^{28}$

Dari pemikiran Shaleh Darat ini, bisa ditarik satu relevansi dengan kondisi sosial politik yang dialaminya. Pada saat itu, Pemerintah Belanda telah melakukan kebijakan dengan membungkam segala kebaikan dan melarang umat Islam untuk mempelajari isi kandungan Alquran. Apa yang dilakukan oleh Shaleh Darat adalah sebagai bentuk kritik sosial terhadap Pemerintah Belanda. Seperti ketika menjelaskan QS. al-Nisāa [4]: 66:

${ }^{28}$ Ibid., 312. 


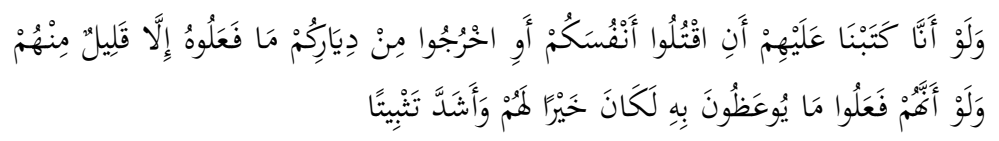

"Dan sesungguhnya kalau Kami perintahkan kepada mereka: "Bunuhlah dirimu atau keluarlah kamu dari kampungmu", niscaya mereka tidak akan melakukannya kecuali sebagian kecil dari mereka. Dan sesungguhnya kalau mereka melaksanakan pelajaran yang diberikan kepada mereka, tentulah hal yang demikian itu lebih baik bagi mereka dan lebih menguatkan iman mereka."

Bunuhlah dirimu dalam ayat di atas, menurut Shaleh Darat adalah dengan "membunuh sesuatu yang mengotori nafsu" dan "membunuh sesuatu yang disenangi nafsu". Jika manusia mampu membunuh sesuatu yang dapat mengotori nafsu, maka nafsu bisa tunduk dan patuh kepada Allah. Sehingga akan mendapatkan pancaran cahaya Ilahi.

Penafsiran Shaleh Darat di atas, jika dikaitkan dengan konteks di mana tafsir itu ditulis, Belanda telah bertindak sewenang-wenang dengan melakukan berbagai penindasan. Belanda adalah cermin ketakaburan, kesombongan dan kecongkakan. Sifat-sifat tersebut di atas telah mengotori nafsu. Sehingga harus diperangi karena bertentangan dengan nilai-nilai ajaran Islam.

Dalam salah satu kitabnya yang berjudul Munjiyat, Shaleh Darat menjelasan tentang sifat kibr (sombong) dan harus dijauhi, karena termasuk dosa besar:

"Setuhune kibir iku didum atas rong perkara: ana bathin la nana dhahir, maka kibir bathin itu iya pekerti ing ndalem ati lan iya iku kelawan rumangsa ing ndalem atine setuhune awake iku angungguli ing liyane ing ndalem sifat kesempurnaan. Maka utawi kibir dhahir maka iku pira-pira penggawene kang dhahir. Maka kibir ing ndalem ati lan takabur ing ndalem penggawehane ndahir kaya yen lelungguhan ora gelem asor lan yen caturan ora gelem kalah lan lamun den ina wong maka bendu lan lamun ora den tatakramani maka iya bendu. Lan lamun maturi manungsa maka kelawan keras, lan lamun den tuturi maka bengis, maka lamun muruki santri maka ora welas maring santri lan ngina-ngina, lan lamun kongkon maka keras, lan lamun ningali wong awam kang bodo-bodo maka kaya ningali kebo lan sapi ing ndalem bodone. Maka iku kabeh takabur arane."29

${ }^{29}$ Muḥammad Ṣaliḥ b. 'Umar al-Samarāni, Kitāb Munjizyat (Semarang: Thaha Putra, t.th.), 39-40. 
Sikap Belanda yang berlaku sewenang-wenang dan menindas terhadap masyarakat pribumi adalah sebagai bentuk kesombongan. Belanda menganggap dirinya lebih unggul, dan warga pribumi dianggap bodoh terbelakang serta diperlakukan sangat kasar. Budaya kolonial Belanda yang demikian, sangat bertentangan dengan nilainilai ajaran Islam.

Pemikiran Shaleh Darat di atas, sampai sekarang ini tampaknya belum mati. Bila suatu bangsa dipimpin oleh orang yang berpikiran jernih, maka akan mampu mengantarkan rakyatnya menuju masyarakat yang adil sejahtera sehingga akan membawa kebaikan dan keberkahan di muka bumi. Dalam pandangan Shaleh Darat, suatu negara yang dibangun berdasarkan ketidakadilan, kesewenangwenangan, perbudakan, dan keculasan maka tidak akan melahirkan kebaikan, kemakmuran dan keberkahan. Belanda telah melakukan penindasan dan eksploitasi terhadap warga pribumi, sehingga terjadi kemiskinan, kelaparan dan krisis pangan yang mengakibatkan penderitaan bagi rakyat Indonesia.

Apa yang telah dilakukan oleh Belanda dengan tegas ditolak oleh Kiai Shaleh Darat. System yang dibangun oleh Belanda harus dimusnahkan dari muka bumi. Segala bentuk kemungkaran akan melahirkkan berbagai tragedi kemanusiaan. Tindakan Belanda yang sewenang-wenang terhadap penduduk pribumi tidak akan memberikan keberkahan bagi seluruh umat manusia. Dengan sistem yang buruk, justru akan membuat bumi dan seluruh isinya tidak akan membawa ketentraman, kedamaian dan keberkahan. ${ }^{30}$

Penjajah telah membungkam segala bentuk kebenaran demi menjaga keutuhan sistem kekuasaan yang jauh dari nilai-nilai kemanusiaan. Kondisi yang demikian oleh Shaleh Darat dilawannya dengan sejumlah karyanya. Shaleh Darat berusaha untuk membangkitkan pemikiran masyarakat dengan melakukan pencerahan jiwa, mental, pemikiran dan spiritual. Melalui karya tafsir yang ditulis dengan corak sufinya telah menjadi ruh di setiap lembarnya sekaligus sebagai pintu utama dalam membina masyarakat dengan menanamkan nilai-nilai kebaikan.

${ }^{30}$ Hakim, Kyai Shaleh, 108. 


\section{Kontribusi Kiai Shaleh Darat dalam Penulisan Tafsir di Indonesia}

Tafsir Fayd al-Raḅmān yang ditulis oleh Shaleh Darat merupakan salah satu tonggak penting bagi masyarakat di Jawa, karena ajaran Islam dapat diperkenalkan langsung dari kitab sucinya. Di saat Pemerintah Belanda membangun tembok yang tinggi untuk menentang Islam dan berusaha membatasi pengaruh Islam di Jawa. Para pelajar di sekolah-sekolah Belanda diintimidasi agar mereka tidak mempelajari Islam. Masyarakat di Jawa tidak diperbolehkan memahami ajaran Alquran.

Dalam konteks penulisan tafsir Alquran, Shaleh Darat mempunyai keberanian di tengah hegemoni Belanda yang ketika itu melarang umat Islam di Nusantara untuk menerjemahkan Alquran. Keberaniannya melawan arus sehingga berhasil mendobrak segala bentuk keangkuhan. Atas jasanya, banyak masyarakat khususnya di Jawa bisa memahami ajaran Islam. Melalui karya tafsirnya, beliau tidak hanya memberikan pemahaman tentang isi kandungan Alquran, tetapi sekaligus sebagai bentuk perlawanan terhadap pemerintah Belanda. Perlawanan secara kultural yang dikemas dalam kajian-kajian tasawuf.

Sebagai ulama di Nusantara, Shaleh Darat adalah salah satu tokoh penulis tafsir Alquran dengan Bahasa Arab Pegon yang mempunyai proses transmisi keilmuan yang jelas dari Timur Tengah. Pengalaman akademiknya ditempuh dari pesantren ke pesantren terus ke Timur Tengah yang kemudian menggerakkan dirinya untuk melakukan pengajaran Islam dan sekaligus perlawanan terhadap Belanda melalui sejumlah karya-karyanya.

Strategi dakwahnya dalam menyebarkan Islam di Jawa, dengan cara mentransformasikan Islam ke dalam konteks bahasa lokal, sehingga ajaran Islam mudah dipahami dan dipraktikan oleh masyarakat Jawa. Dengan mengusung bahasa Jawa (arab pegon), bukan semata-mata sebagai representasi identitas kejawaan, tetapi sebagai sarana untuk melakukan perlawanan terhadap kolonial Belanda dan sekaligus sebagai penggerak di dalam proses pengenalan atas makna-makna ayat-ayat Alquran. Dengan demikian, Shaleh Darat masih bisa menerjemahkan Alquran dan menyebarkan ajaran Islam tanpa harus khawatir dicurigai oleh Belanda.

Apa yang telah dilakukan oleh Shaleh Darat adalah wujud nyata dalam menggali mutiara-mutiara yang ada di dalam Alquran. Walaupun tembok tinggi berdiri dengan kokoh, namun ia mampu 
mendobraknya. Kepiawaiannya dalam mengaitkan penjelasan terkait keagamaan dengan kondisi riil yang dialami telah menjadi sukma dan energi bagi santri-santrinya untuk berjuang melawan penjajah.

Shaleh Darat memang bukan orang yang pertama kali dalam menulis sejumlah karyanya dengan huruf pegon. Sebab sebelumnya, sudah ada yang menulis dengan memakai aksara pegon seperti yang dilakukan oleh Kiai Ahmad Rifa'i (1786-1869 M) asal Kalisalak. Ia dalam menulis sejumlah karyanya yang masih dalam bentuk manuskrip dengan menggunkan bahasa pegon, seperti Tanbih, Husn alMitalab, Takbriyah, Abyan al-Hawaij, Nadam Arfa', Munawwir al-Himmah, Tasyribah al-Mubtaj, Nadham Athlab, Nadham Tazkiyah, Syarikh alImam. ${ }^{31}$ Namun demikian, keberadaan tafsir Fayd al-Rahmān semakin menguatkan eksistensi tafsir di Nusantara, sehingga bisa dijadikan sebagai sumber rujukan dalam penafsiran. Meskipun Shaleh Darat baru menulis tafsirnya dua jilid (Juz 6) saja dan belum mencakup seluruh Alquran, namun tetap menyumbang keilmuan tafsir di Nusantara.

Karya tafsirnya yang bernuansa sufistik sebagai pintu utama dalam membina masyarakat dalam menanamkan nilai-nilai kebaikan dan kebenaran. Sehingga mampu membangkitkan pemikiran dan penyegaran rohani serta dapat memberikan pencerahan jiwa dan mental. Dalam konteks masyarakat Indonesia yang masih dalam cengkeraman penjajah, melalui pendekatan tasawuf, Shaleh Darat menegaskan sebuah makna bahwa sebelum bangsa Indonesia mencapai kemerdekaan secara jasmani, maka pertama yang harus ditempuh adalah kemerdekaan secara rohani. Sebelum kemerdekaan materiil dicapai, maka yang harus dilakukan terlebih dahulu adalah kemerdekaan spiritual. Jiwa-jiwa masyarakat di Nusantara harus dimerdekakan terlebih dahulu. ${ }^{32}$

Shaleh Darat adalah salah satu ulama yang telah memberikan pencerahan dan pemikiran kepada masyarakat dengan menanamkan semangat untuk menolak pengaruh-pengaruh kolonialisme, dan mendidik para santrinya semangat berjuang untuk membela tanah air. Pemikiran Shaleh Darat dengan anti-kolonialisme yang akhirnya berhasil menumbuhkan semangat nasionalisme kepada para santrinya. Kenyataan ini menunjukkan bahwa aktivitas keilmuan Shaleh Darat

31 Gusmian, Dinamika Tafsir, 178.

${ }^{32}$ Hakim, Kyai Shaleh, 102. 
telah memberikan pengaruh kuat di dalam proses penyebaran Islam dan pergerakan di Jawa.

Shaleh Darat sebagai salah satu tokoh intelektual muslim di Nusantara yang hidup pada abad ke-19 mempunyai kredibilitas intelektual secara mendalam di berbagai bidang kajian Islam. Penjelasan ajaran-ajaran Islam lewat aksara Pegon yang dilakukannya telah membuat masyarakat Jawa mampu mencerna dan memahami ayat-ayat Alquran.

Sebuah karya tafsir adalah hasil ijtihad (produk) manusia, dan sebagai ijtihad tidak ada karya tafsir yang sempurna, baik dari aspek metode penulisannya, sistematikanya atau yang lainnya. Masingmasing karya tafsir tentu mempunyai kelebihan dan kekurangannya. Demikian pula dengan tafsir Fayd al-Rahmān disamping memiliki kelebihan juga tidak lepas dari kekurangannya. Adapun kelebihan dan kekurangannya adalah: 1) Tafsir Fayd al-Raḥmān ditulis dengan menggunakan Bahasa Jawa (Arab Pegon). Tafsir ini memang cocok untuk masyarakat Jawa karena mudah dibaca dan dipahami tidak hanya dari kalangan kaum santri. Dengan mengusung Arab Pegon karena menyesuaikan kondisi masyarakat Jawa yang tidak bisa berbahasa Arab; 2) Kitab tafsir ini mampu memberikan informasi tentang persoalan yang dihadapi oleh umat Islam, seperti: hukum, tauhid, tasawuf dan pokok-pokok ajaran agama.

Adapun kelemahannya, di antaranya adalah: 1) Dalam mencantumkan hadis, tidak disertakan sanadnya secara lengkap. Secara metodologi dalam penulisan setiap ayat yang ditafsirkan tidak diberi nama surah dan nomor ayat, sehingga menyulitkan pembaca dalam mencari ayat yang dibutuhkan; 2) Shaleh Darat dalam menulis karya tafsirnya menggunakan bahasa yang ragam, kadang Bahasa Jawa ngoko dengan menggunakan nuansa Jawa Pesisiran dan Bahasa Jawa Pedalaman sehingga sulit dipahami bagi masyarakat Jawa modern.

Tidak jauh berbeda dengan rumusan di atas, Abdul Mustaqim menyajikan empat kontribusi besar Kiai Shaleh. ${ }^{33}$ Pertama, sebagai penulis pertama kitab tafsir berbahasa Jawa. Hal demikian memberikan pengaruh karena ulama sebelum Shaleh Darat menulis tafsir dengan bahasa Melayu atau Arab. Dengan demikian, ia telah melakukan transmisi pengetahuan secara signifikan pada saat itu.

33 Lihat Abdul Mustaqim, Tafsir Jawa: Eksposisi Nalar Shufi-Isyäri Kiai Shaleh Darat; Kajian atas Surah al-Fätihah dalam Kitab Faidl al-Rahman (Yogyakarta: Idea Press, 2018), 65-76. 
Kedua, meneguhkan identitas Jawa dalam tafsir. Shaleh Darat menegaskan bahwa ilmu yang bermanfaat tidak harus ditulis dalam bahasa Arab. Hal ini menurut Abdul Mustaqim memiliki signifikansi karena telah menjembatani keilmuan Alquran dengan kultur Jawa.

Ketiga, pengusung gagasan wasatiyah (moderat) aswaja. Gagasan "moderat" di sini adalah elemen menjalani ritual ibadah yang tidak hanya menekankan sisi lahir, namun juga batin, dengan demikian tidak akan terjebak pada pemahaman tekstualis. Demikia juga tidak fanatik pada hakikat, hingga mengabaikan syariat, kedua dimensi tersebut harus terkait kelindan hingga menimbulkan keseimbangan sosial maupun spiritual. Keempat, pengusung epistemologi 'irfanì. Di tengah corak tafsir yang kala itu didominasi oleh epistemology bayani, tafsir Shaleh Darat seolah memberikan opsi dinamika penulisan tafsir. Dengan epistemologi itu, Shaleh Darat seakan berusaha "mendamaikan konflik antara kaum syariat formalis yang sangat rigid dalam memahami ajaran Islam, dengan kelompok batini $\bar{i}$ yang lebih mengedepankan aspek hakikat." ${ }^{34}$

\section{Kesimpulan}

Shaleh Darat merupakan salah satu tokoh yang mempunyai kontribusi yang sangat besar dalam penulisan tafsir di Indonesia yang mempunyai keberanian mendobrak tembok yang tinggi yang dibangun oleh Belanda. Di tengah hegemoni Belanda yang ketika itu melarang umat Islam di Nusantara untuk menerjemahkan Alquran, ia berani melawan arus sehingga berhasil melawan segala bentuk keangkuhan dan kesombongan. Melalui karya-karyanya yang ia torehkan, tidak hanya memberikan pemahaman tentang isi kandungan Alquran, tetapi sekaligus sebagai bentuk perlawanan terhadap pemerintah Belanda, sebuah bentuk perlawanan kultural yang dikemas dalam kajian-kajian tasawufnya. Keberadaan tafsir Fayd al-Rahmān semakin menguatkan eksistensi tafsir di Nusantara, sehingga bisa dijadikan sebagai sumber rujukan dalam penafsiran untuk memperkaya khazanah tafsir di Nusantara.

34 Ibid., 76. 


\section{Daftar Pustaka}

Baidan, Nasruddin. Metodologi penafsiran al-Qur'an. Yogyakarta: Pustaka Pelajar, 2000

Faiqoh, Lilik. "Vernakularisasi dalam Tafsir Nusantara: Kajian atas Tafsir Faid al-Rahman Karya Kiai Shaleh Darat." Jurnal Living Islam, Vol. 01, No, 01 (2018).

Gusmian, Islah. "Bahasa dan Aksara dalam Penulisan Tafsir AlQur'an di Indonesia Era Awal Abad 20 M." Mutawatir Jurnal Keilmuan Tafsir Hadith, Vol. 5, No. 2 (2015).

Gusmian, Islah. Dinamika Tafsir al-Qur'an Bahasa Jawa. Surakarta: EFUDE PRESS, 2015.

Gusmian, Islah. Khazanah Tafsir Indonesia dari Hermeneutika bingga Ideologi. Jakarta: Teraju, 2003

Hakim, Taufiq. Kyai Shaleh Darat dan Dinamika Politik di NusantaraAbad XIX-XX. Yogyakarta: INDeS, 2016

Musbikin, Imam. Mutiara al-Qur'an. Yogyakarta: Jaya Star Nine, 2014

Mustaqim, Abdul Tafsir Jawa: Eksposisi Nalar Shufi-Isyäri Kiai Shaleh

Darat; Kajian atas Surah al-Fatihah dalam Kitab Faidl al-Rabman. Yogyakarta: Idea Press, 2018

Rohman, Taufikur. "Kajian Tafsir di Indonesia." Mutawatir Jurnal Keilmuan Tafsir Hadith, Vol. 2, No. 1 (2012).

Samarani (al), Muhammad Shaleh b. Umar. Kitab Munjiyat. Semarang: Thaha Putra, tt

Samarani (al), Muhammad Shaleh b. Umar. Maha Guru Ulama' Nusantara, terj. Sabilul "Abid "Ala Jauharah At-taubid. Bogor: Sahifa, 2017

Samarani (al), Muhammad Shaleh b. Umar. Syarah al-Hikam: Kyai Shaleh Darat, Maha Guru Ulama Besar Nusatara 1820-1903, terj. Miftahul Ulum dan Agustin Mufarohah. Depok: Penerbit Sahifa, 2016

Samarani (al), Muhammad Shaleh b. Umar. Tafsir Fayd al-Rahmān fi Tarjamat Tafsìr Kalām al-Mälike al-Dayyān. Mesir: tt., 1935

Tim Buku Tempo. Gelap-Terang Hidup Kartini, Perempuan-perempuan Perkasa. Bogor: PT GrafikaMardi Yuana, 2018

Ulum, Amirul. Kartini Nyantri. Yogyakarta: Pustaka Ulama, 2016

Wawancara dengan Lukman Hakim Sektiawan salah satu cicit Kiai Shaleh Darat, pada tanggal 15 Juli 2018. 